\title{
Late prehistoric coastal settlement patterns in the Cantabrian region, northern Spain
}

Joseba Rios-Garaizar ${ }^{1, *}$, Miriam Cubas ${ }^{2}$, Diego Garate Maidagan ${ }^{3}$, Iñaki Libano Silvente ${ }^{4}$, Ander Ugarte Cuétara ${ }^{4}$, Sergio Vega López ${ }^{4}$, Encarnación Regalado Bueno ${ }^{4}$, Aixa San Emeterio Gómez ${ }^{1,4}$ Jesús Tapia ${ }^{5}$, Alejandro García Moreno ${ }^{6}$, Alesander Trebolazabala Hurtado $^{4} \&$ Arkaitz Aketxe Agirre ${ }^{4}$

Newly discovered archaeological sites in the Uribe Kosta region of northern Spain are illuminating the establishment of late prehistoric coastal farming settlements and specialised tool-production activities.

The modification of settlement patterns and habitats in permanent open-air villages is traditionally linked to the Neolithic expansion in Central Europe and the Mediterranean. Archaeological research allows for the identification and study of these sites in order to understand the socio-economic and cultural development of the earliest farmer communities. A dearth of archaeological evidence, however, hampers our interpretation of the Neolithisation of some regions, such as northern Spain. Here, research has been traditionally focused on archaeological contexts associated with caves and megalithic structures, with some limited references to Neolithic, Chalcolithic and Bronze Age open-air sites (e.g. Gorrotxategi et al. 1995; Iriarte et al. 2005; Mujika et al. 2009; Fernández Mier \& González-Álvarez 2013; Regalado Bueno et al. 2015; Cubas et al. 2016).

This paper presents the first evidence for coastal occupation farming communities in the Uribe Kosta region during late prehistory (Figure 1). Until recently, this unique arealocated in the Basque Country, on the eastern part of the Cantabrian coast-has received little systematic archaeological research. Since 2007, however, interest in this issue has increased, and several new sites have been discovered and investigated (e.g. Rios-Garaizar et al. 2007).

1 Centro Nacional de Investigación sobre la Evolución Humana (CENIEH), Paseo Sierra de Atapuerca 3, E-09002 Burgos, Spain

2 Sociedad de Ciencias Aranzadi-University of York, Zorroagagaina 11, E-20014 Donostia, Spain

3 Instituto Internacional de Investigaciones Prehistóricas de Cantabria (IIIPC), Edificio Interfacultativo, Avenida de los Castros s/n, E-39005 Santander, Spain

4 Edestiaurre Arkeologia Elkartea. Liburutegi Barrika, Udaletxeko Bidea 2, E-48650, Barrika, Spain

5 Sociedad de Ciencias Aranzadi, Zorroagagaina 11, E-20014 Donostia, Spain

6 Museo de Prehistoria y Arqueología de Cantabria MUPAC, Calle Bailén s/n, E-39004, Santander, Spain

* Author for correspondence (Email: joseba.rios@cenieh.es)

(C) Antiquity Publications Ltd, 2018 ANTIQUITY 92 364, e2 (2018): 1-7 


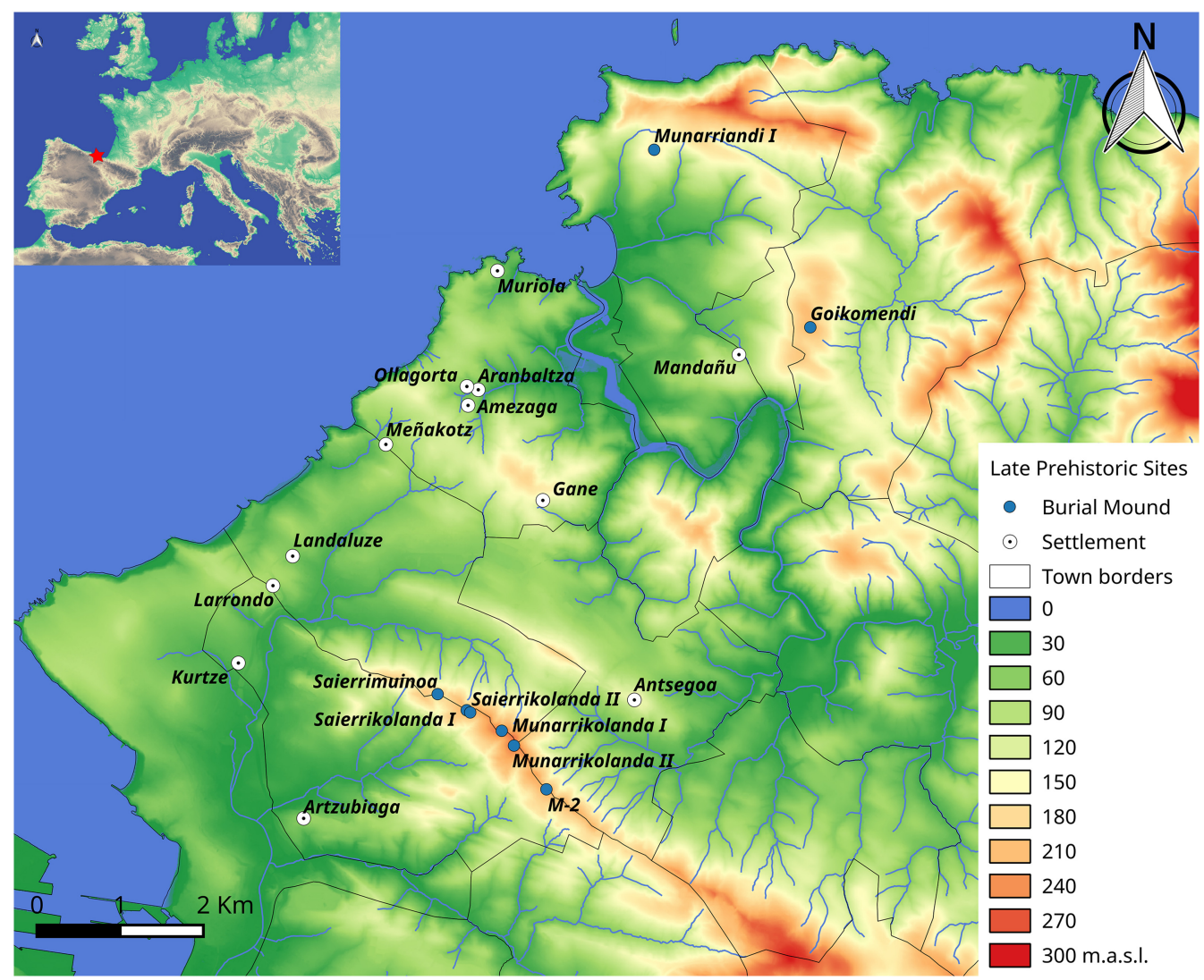

Figure 1. Map of the Uribe Kosta area with the location of the most relevant late prehistoric sites. Base map created using LiDAR $20161 \times 1 m$ data (www.geoeuskadi.eus).

In 2013 we initiated a systematic research project ('First Farming Communities in the Coastal Region of Biscay'), excavating newly discovered open-air sites, carrying out landscape surveys to identify burial mounds and reviewing material culture (e.g. polished tools, pressure-blade cores, arrowheads and grinding stones) (Regalado Bueno et al. 2015; Ugarte Cuétara 2015; Rios-Garaizar et al. 2016) (Figure 2).

Aranbaltza II (research campaigns from 2013-2015) and Landaluze (2015 campaign) are the most interesting of the recently discovered sites (Regalado Bueno et al. 2015; Rios-Garaizar et al. 2016). The former yielded a Holocene palaeosoil and a ChalcolithicEarly Bronze hearth (c. 2880 and 1975 cal BC). Lithic materials included flake and blade fragments, cores and a single stemmed and winged bifacial point, along with evidence of pressure blade flaking. At Landaluze (Figure 3), a large surface lithic assemblage and two heated-stone combustion structures were excavated, the latter dating to 4240-3990 cal BC (calibrated at $95.4 \%$ confidence using OxCal 4.3 and IntCal13 calibration curve, Bronk Ramsey 2009; Reimer et al. 2013) (Figure 3) (Regalado Bueno et al. 2015). Ongoing 


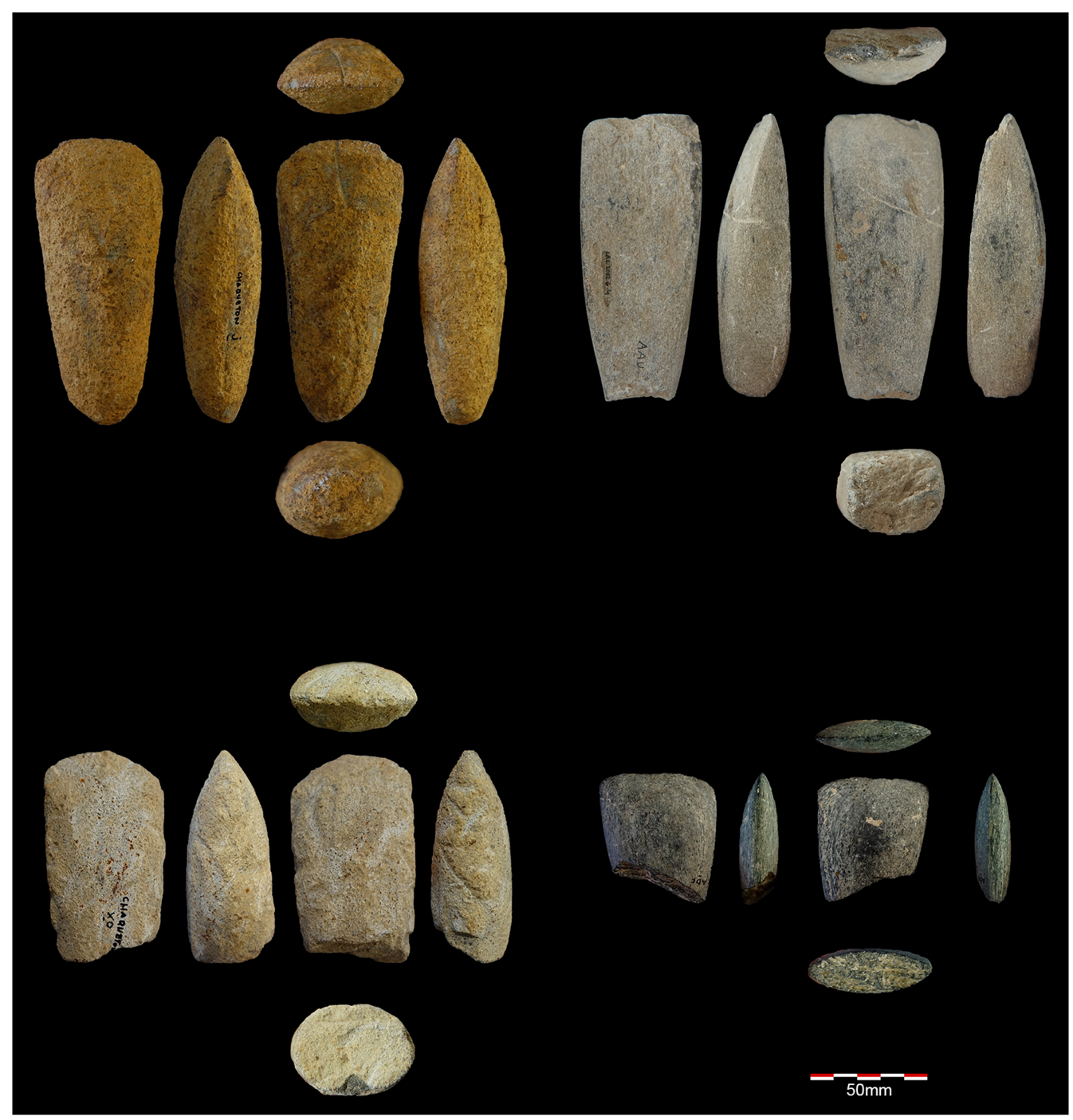

Figure 2. Polished axes from Uribe Kosta sites: 1) Kurtze; 2) Landaluze; 3) Kurtze; 4) Kurtze (adapted from Ugarte Cuétara 2015).

investigations suggest that these two sites may represent different activity areas of permanent and long-term continuous settlements.

This programme has also identified new funerary structures around these sites. The archaeological record, however, is poorly preserved. As the area today is heavily populated, many archaeological contexts have been altered substantially, or even destroyed, by urban development, roadworks or quarrying. Using remote-sensing prospection (LiDAR) combined with in situ verification, we have discovered new burial mounds in Munarriandi (Rios-Garaizar et al. 2017) and Goikomendi (Figure 4), both situated adjacent to the River Butron. An integrated approach focused on both domestic and funerary archaeological sites,

(C) Antiquity Publications Ltd, 2018 
Joseba Rios-Garaizar et al.

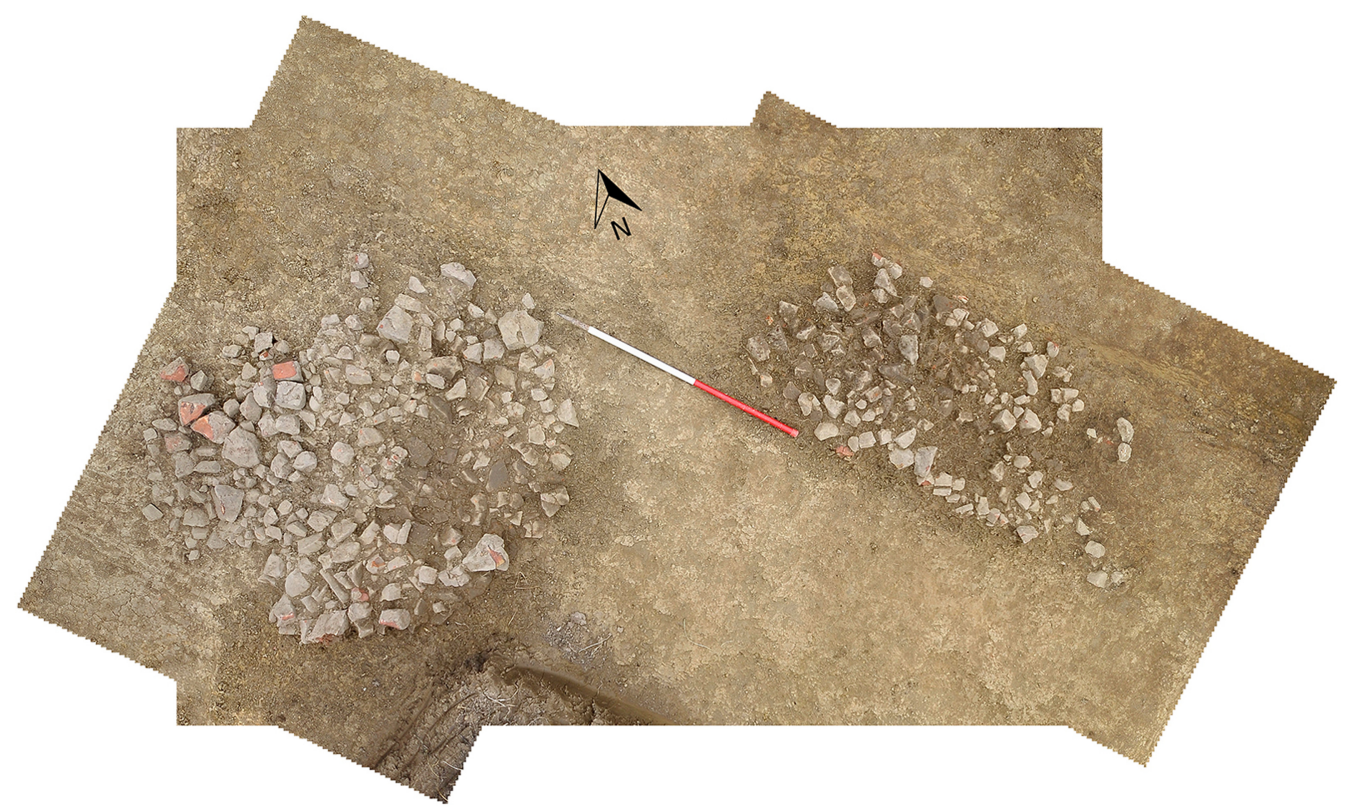

Figure 3. Heated-stone combustion structures from Landaluze (adapted from Regalado Bueno et al. 2015) (photograph by Natxo Pedrosa).

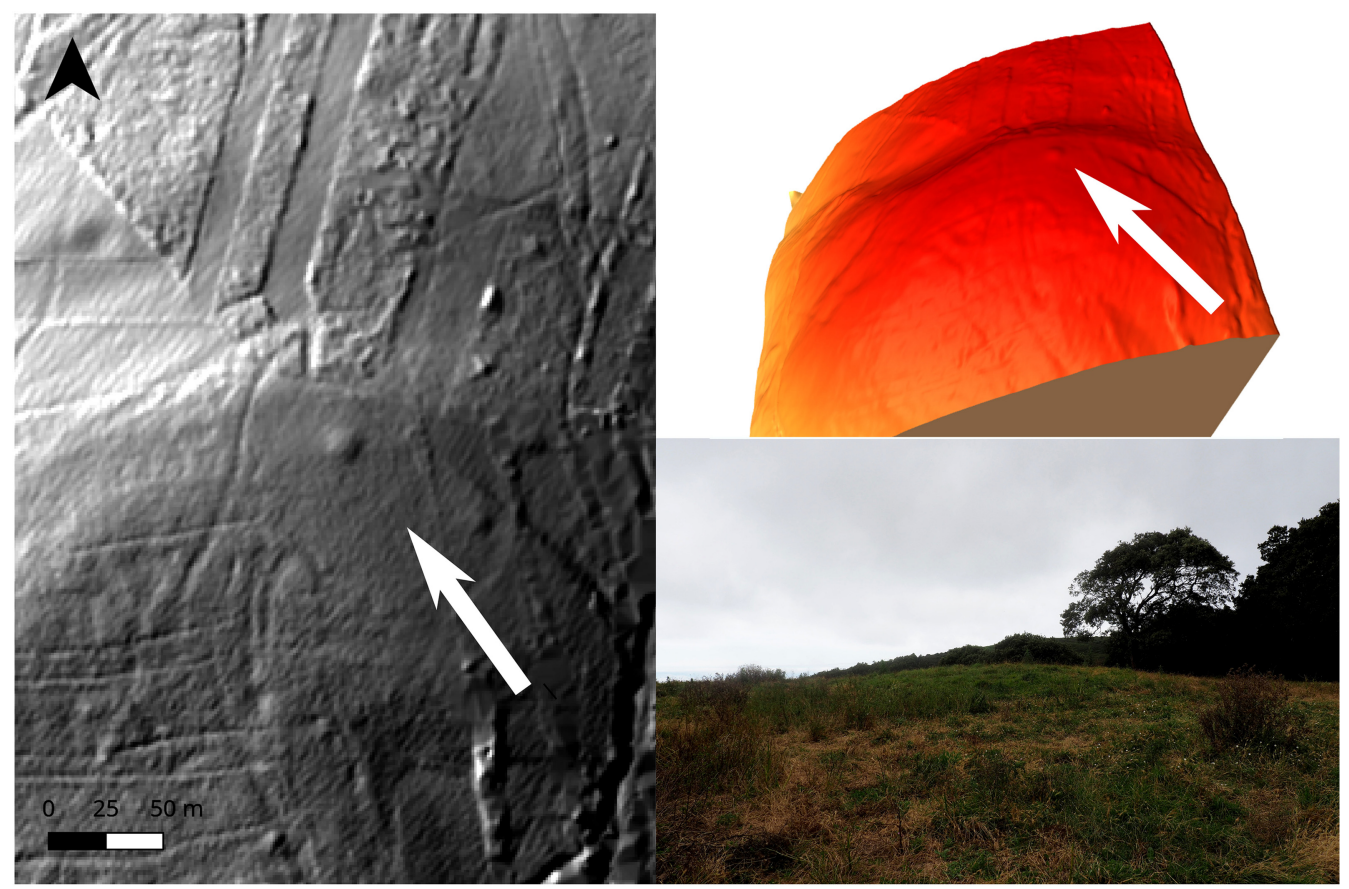

Figure 4. Burial mound remote sensing. Munarriandi I: left) hillshade projection (Qgis-raster terrain analysis plugin, $Z$ factor: 3.0, Azimut: $300^{\circ}$, vertical angle: $40^{\circ}$ ); top right) $3 D$ view (Qgis2threejs plugin, vertical exaggeration: 3.0); bottom right) view of the burial mound (photograph by Joseba Rios-Garaizar).

(C) Antiquity Publications Ltd, 2018 
along with the excavation of these burial mounds, will allow us to investigate how different territories and landscapes were utilised during late prehistory.

The richness of the lithic assemblage is probably influenced by the existence of a local, highly productive and long-exploited flint outcrop. Technological analyses focus on the classification of pressure-flaking cores for the production of blades. Currently, more than 200 pressure-flaking blade cores have been recorded throughout the area, most of which were intended for the production of relatively short, narrow and thin blades. Sites such as Meñakotz or Larrondo have produced large quantities of cores, suggesting the presence of blade-production workshops (Figure 5). Locally produced blades, however, are less frequently represented at these sites, suggesting that they were made for exportation.

Similarly, bifacial arrowheads are typologically and technologically representative of late prehistory in northern Spain. Preliminary observations suggest a relatively simple production process, starting from simple cortical and thick flakes. Some of the points display diagnostic impact damage, while others seem to have been broken during production. Few of these points are made of non-local flint. Finally, different morphologies (Figure 6) suggest a wide chronology for these points, from the Late Neolithic to Bronze Age. Ceramics are rare at the aforementioned sites, and are limited to non-diagnostic sherds. Metal is also poorly

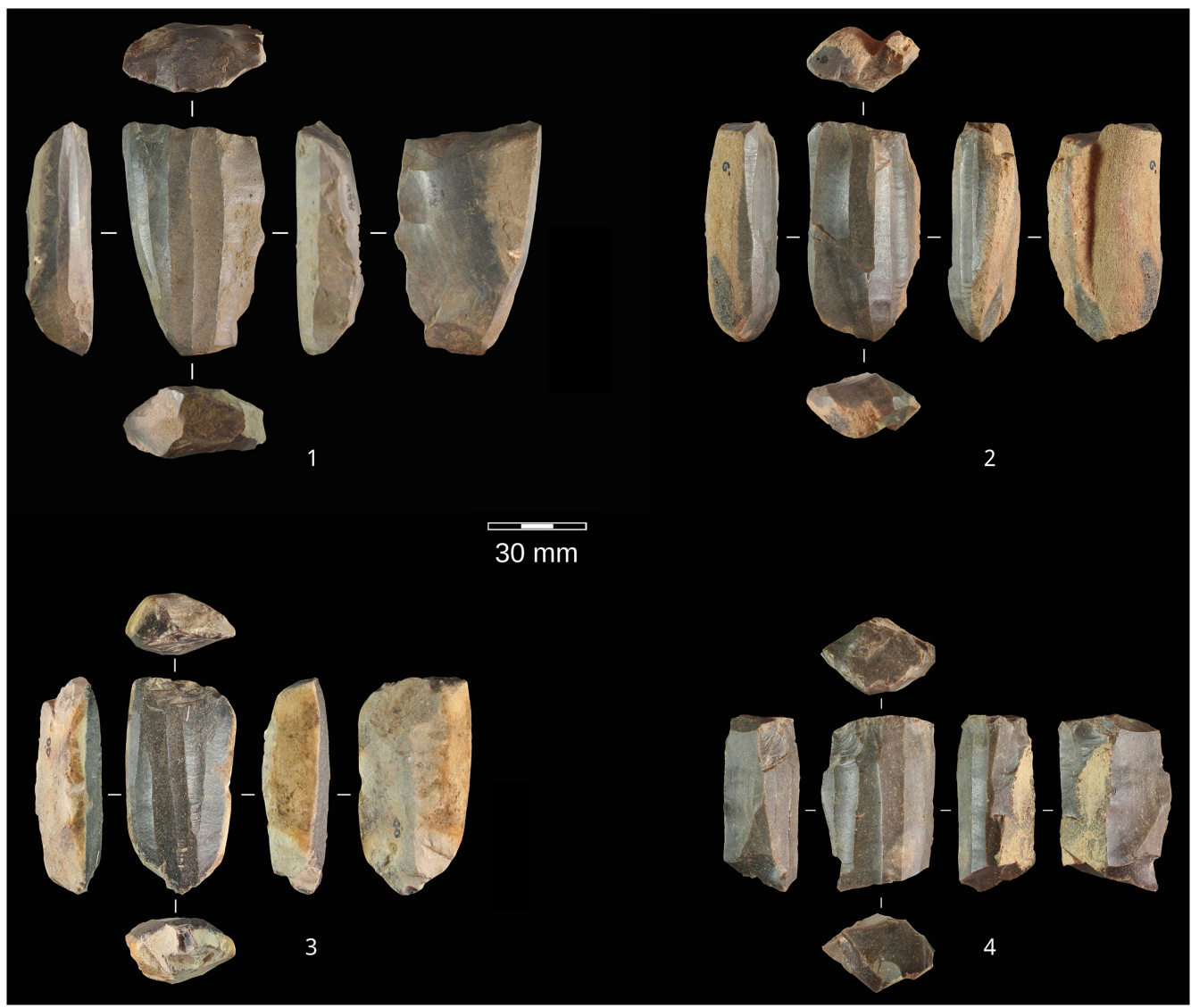

Figure 5. Pressure-flaking blade cores from Larrondo (photographs by S. Vega-Lopez and I. Libano Silvente).

(C) Antiquity Publications Ltd, 2018 


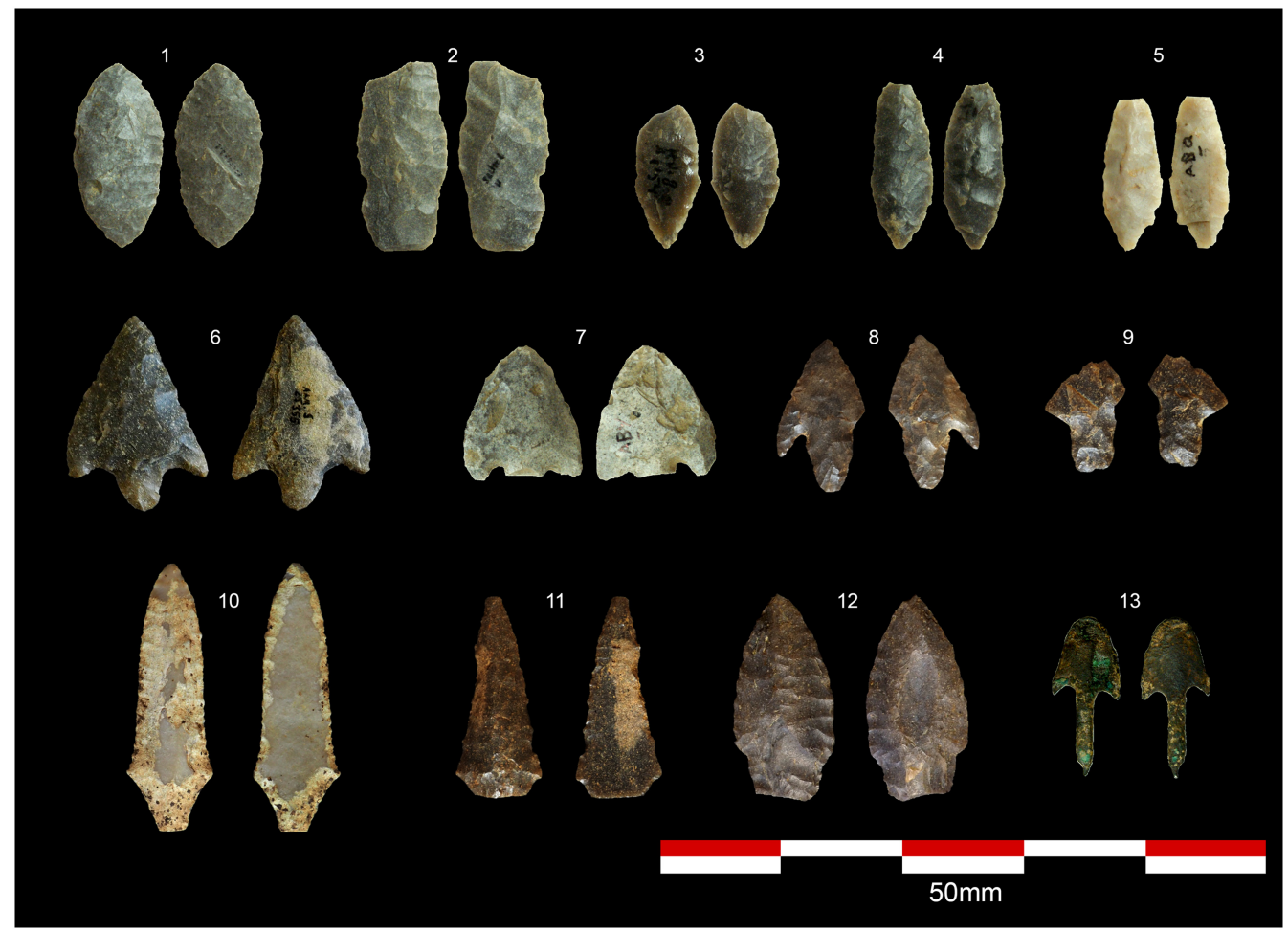

Figure 6. Arrowheads from Uribe Kosta. Bifacial points: 1-12; Palmela point: 13; from A. Aguirre collection (photographs by D. Garate Maidagan and J. Rios-Garaizar).

represented, the most diagnostic artefact being a Palmela point (c. $3000 \mathrm{cal} \mathrm{BC})$, recovered from a disturbed context in Kurtzia (Barandiarán et al. 1960) (Figure 6.13).

Preliminary data suggest that the establishment of farming communities in the Uribe Kosta region was clearly more complex than previously considered, with strong evidence for permanent settlements, specialised products and the symbolic transformation of the landscape. Our ongoing research will continue to: 1) identify and excavate new, wellpreserved settlements and funerary monuments; 2) establish local chronologies, settlement patterns and environment interactions; and 3) analyse archaeological remains to evaluate the establishment of farming activities and the production of goods for exportation.

\section{References}

Barandiarán, J.M., A. Aguirre \& M. Grande. 1960. Estación de Kurtzia (Barrica-Sopelana). Bilbao: Servicio de Investigaciones Arqueológicas de la Excma, Diputación Provincial de Vizcaya.

Bronk Ramsey, C. 2009. Bayesian analysis of radiocarbon dates. Radiocarbon 51: 337-60. https://doi.org/10.1017/S0033822200033865

Cubas, M., J. Altuna, E. Álvarez-Fernández, A. Armendariz, M.Á. Fano, I.L. López-Dóriga,

(C) Antiquity Publications Ltd, 2018
K. Mariezkurrena, J. Tapia, L.C. Teira \& P. ArIAs. 2016. Re-evaluating the Neolithic: the impact and the consolidation of farming practices in the Cantabrian region (northern Spain). Journal of World Prehistory 29: 79-116. https://doi.org/10.1007/s10963-016-9091-2

Fernández Mier, M. \& D. GonzÁlez Álvarez. 2013. Más allá de la aldea: estudio diacrónico del paisaje en el entorno de Vigaña (Belmonte de Miranda). Excavaciones arqueológicas en Asturias 2007-2012: 353-65. 
Gorrotxategi, J., M.J. Yarritu, M. Kandina \& T. SAGarduy. 1995. El poblado de montaña calcolítico de Ilso Betaio (Bizkaia). Estructuras de habitación, materiales arqueológicos, estudio palinológico y antracológico. Isturitz, Cuadernos de Sección, Prehistoria-Arqueología 6: 3-204.

Iriarte, M.J., J.A. Mujika \& A. Tarriño. 2005. Herriko Barra (Zarautz-Gipuzkoa): caractérisation industrielle et économique des premiers groupes de producteurs sur le littoral basque, in G. Marchand \& A Tresset (ed.) Unité et diversité des processus de néolithisation sur la façade atlantique de l'Europe (Mémoire XXXVI): 127-36. Paris: Société Préhistorique Française.

Mujika, J.A., X. Peñalver, A. Tarriño \& E. Tellería. 2009. Haltzerreka (Gipuzkoa): un asentamiento del Bronce Antiguo al aire libre en un medio de montaña. Kobie 28: 89-120.

Regalado Bueno, E., A. San Emeterio, J. Ríos Garáizar, D. Gárate Maidagan, Z. Marcos Gómez, A. Ugarte Cuetara, I. Líbano Silvestre, M.Á. Medina-Alcaide, A. Moreno Larrazabal \& A.J. Pérez Fernández. 2015. El yacimiento al aire libre de Landaluze (Sopela, Bizkaia): una nueva ocupación neolítica en la costa cantábrica. Kobie 34: 19-40.

Reimer, P.J., E. Bard, A. Bayliss, C.W. Beck, P.G. Blackwell, C. Bronk Ramsey, C.E. Buck, H. Cheng, R.L. Edwards, M. Friedrich, P.M.
Grootes, T.P. Guilderson, H. Haflidason, I. Hajdas, C. Hatté, T.J. Heaton, D.L. Hoffmann, A.G. Hogg, K.A. Hughen, K.F. Kaiser, B. Kromer, S. Manning, M. Niu, R. W. Reimer, D.A. Richards, E. Marian Scott, J.R. Southon, R.A. Staff, C.S.M. Turney \& J. Van Der Plicht. 2013. INTCAL13 and Marine 13 radiocarbon age calibration curves 050,000 years cal BC. Radiocarbon 55: 1869-87. https://doi.org/10.2458/azu_js_rc.55.16947

Rios-Garaizar, J., D. Garate, L. Zapata-Peña, Z. Marcos \& E. Regalado Bueno. 2007. El yacimiento prehistórico al aire libre de Mandañu (Gorliz, Bizkaia). Kobie 27: 5-19.

Rios-Garaizar, J., I. Ortega, A. San Emeterio Gómez, I. Libano, E. Iriarte \& D. Garate. 2016. Aranbaltza. Yacimiento paleolítico al aire libre. Arkeoikuska: Investigación arqueológica 2015: 165-67.

Rios-Garaizar, J., J. Tapia, M. Cubas, I. Libano, A. Trebolazabala, A. Aketxe, S. Vega \& D. GARATE. 2017. Informe de localización de tres estructuras tumulares en el alto de Munarriandi (Gorliz). Report presented to the Diputación Foral de Bizkaia, Bilbao.

Ugarte Cuétara, A. 2015. Hachas pulimentadas como fuente de estudio de la prehistoria reciente de Uribe Kosta (Bizkaia). Unpublished MA dissertation. 